\title{
Estimating net anthropogenic nitrogen inputs (NANI) in the Lake Dianchi basin of China
}

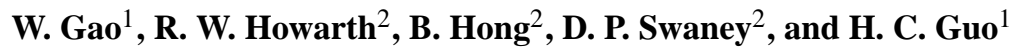 \\ ${ }^{1}$ College of Environmental Sciences and Engineering, Peking University, Beijing 100871, China \\ ${ }^{2}$ Department of Ecology and Evolutionary Biology, Cornell University, Ithaca, NY 14850, USA \\ Correspondence to: H. C. Guo (guohc@pku.edu.cn)
}

Received: 20 January 2014 - Published in Biogeosciences Discuss.: 14 March 2014

Revised: 7 July 2014 - Accepted: 19 July 2014 - Published: 28 August 2014

\begin{abstract}
Net anthropogenic nitrogen inputs (NANI) with components of atmospheric $\mathrm{N}$ deposition, synthetic $\mathrm{N}$ fertilizer, agricultural $\mathrm{N}$ fixation and $\mathrm{N}$ in net food and feed imports from 15 catchments in the Lake Dianchi basin were determined over an 11-year period (2000-2010). The 15 catchments range in size from $44 \mathrm{~km}^{2}$ to $316 \mathrm{~km}^{2}$ with an average of $175 \mathrm{~km}^{2}$. To reduce uncertainty from scale change methodology, results from data extraction by area-weighting and land use-weighting methods were compared. Results show that the methodology for extrapolating data from the county scale to watersheds has a great influence on NANI computation for catchments in the Lake Dianchi basin, and that estimates of NANI between the two methods have an average difference of $30 \%$ on a catchment basis, while a smaller difference $(15 \%)$ was observed on the whole Lake Dianchi basin basis. The riverine $\mathrm{N}$ export has a stronger linear relationship with NANI computed by the land useweighting method, which we believe is more reliable. Overall, nitrogen inputs assessed by the NANI approach for the Lake Dianchi basin are $9900 \mathrm{~kg} \mathrm{~N} \mathrm{~km}^{-2} \mathrm{yr}^{-1}$, ranging from 6600 to $28000 \mathrm{~kg} \mathrm{~N} \mathrm{~km}^{-2} \mathrm{yr}^{-1}$ among the 15 catchments. Synthetic $\mathrm{N}$ fertilizer is the largest component of NANI in most subwatersheds. On average, riverine flux of nitrogen in catchments of the Lake Dianchi basin averages $83 \%$ of NANI, far higher than generally observed in North America and Europe. Saturated N sinks and a limited capacity for denitrification in rivers may be responsible for this high percentage of riverine $\mathrm{N}$ export. Overall, the NANI methodology should be applicable in small watersheds when sufficiently detailed data are available to estimate its components.
\end{abstract}

\section{Introduction}

Nitrogen $(\mathrm{N})$ is one of the most abundant elements on earth, controlling the functions, processes and dynamics of many ecosystems (Vitousek and Howarth, 1991). However, over $99 \%$ of nitrogen is in molecular $\mathrm{N}_{2}$, which is available only to nitrogen-fixing bacteria, and not to other organisms that require reactive forms of $\mathrm{N}$, such as nitrate, nitrite, and ammonium (Galloway et al., 2004; Howarth, 2008). Until the 20th century, the global availability of reactive $\mathrm{N}$ was mainly controlled by biological $\mathrm{N}$ fixation and to a lesser extent lightning and volcanic activity (Galloway, 1998). Since the Industrial Revolution, though, the world has entered the new era of the Anthropocene (Crutzen, 2002; Rockstrom et al., 2009), in which human activities have become the dominant driver of global environment change (Steffen et al., 2007). The rate of creation of reactive $\mathrm{N}$ in the world has increased about tenfold since 1860 due to anthropogenic activities (Galloway et al., 2003), and it is estimated that human interference with the nitrogen cycle has exceeded the safe operating boundary of the Earth by a factor of 3.5 (Rockstrom et al., 2009). The enrichment of nitrogen greatly benefits food production on one hand, but on the other hand, $\mathrm{N}$ pollution has numerous adverse effects, including on human health and water quality (Vitousek et al., 1997; Carpenter et al., 1998; Howarth et al., 2000, 2011; Townsend et al., 2003).

Lake Dianchi, listed among the three most polluted lakes and rivers of China, has experienced water quality degradation since the 1970s (Pan and Gao, 2010). Nitrogen surpluses resulting from human activities are considered among the most important factors for serious eutrophication (Yang et al., 2008). Previous studies conducted in the Lake Dianchi basin were mainly focused on analysis of dissolved chemical 
components (Liu et al., 2009; Li et al., 2012) and pollutant emissions (He et al., 2010; Gao et al., 2013). This basin has lacked detailed studies on its nitrogen budgets and relationships with riverine $\mathrm{N}$ exports, an important foundation for environmental policy making. The objectives of this paper are to evaluate the $\mathrm{N}$ input from human activities and to explore the relationship between net anthropogenic $\mathrm{N}$ input (NANI) and riverine $\mathrm{N}$ exports in the basin. Previous work in North America and Europe has demonstrated that, on average, 20 to $25 \%$ of NANI is exported from large river basins or regions in riverine flow (Howarth et al., 1996, 2012; Howarth, 1998; Swaney et al., 2012; Hong et al., 2013). With detailed input alternatives and simple calculations, NANI is considered to be an effective method for assessing the sources of humaninduced $\mathrm{N}$ inputs to the landscape and their potential impacts on riverine export (Hong et al., 2013). Since most past studies of NANI were based on large basins or regions, the characteristics of NANI in a small watershed such as the Lake Dianchi basin are still largely unexplored; in this study we attempt to estimate them for the first time and to determine the limitations and applicability of using the NANI model in a relatively small watershed.

\section{Materials and methods}

\subsection{Characterization of the Lake Dianchi basin}

The Lake Dianchi basin is located in central Kunming, the capital of Yunnan Province in southwestern China $\left(24^{\circ} 29^{\prime} \mathrm{N}\right.$ $\sim 25^{\circ} 28^{\prime} \mathrm{N}, 102^{\circ} 29^{\prime} \mathrm{E} \sim 103^{\circ} 01^{\prime} \mathrm{E}$; Fig. 1), dividing the watersheds of the Yangtze River, the Red River and the Pearl River. The Lake Dianchi basin covers a total area of $2920 \mathrm{~km}^{2}$ (including the area of lake), with an average altitude of $1900 \mathrm{~m}$, and lies in the seven counties of Wuhua, Panlong, Guandu, Xishan, Songming, Jinning, and Chenggong. Land cover in the Lake Dianchi basin was $19.9 \%$ agricultural, $47.3 \%$ forest, $2.5 \%$ grassland, $10.8 \%$ water, and $16.5 \%$ urban in 2008 (Table 1). We divided the basin into 15 catchments by availability of data and previous study (Gao et al., 2013), ranging in size from 44 to $316 \mathrm{~km}^{2}$, with an average area of $175 \mathrm{~km}^{2}$ (not including the area of Dianchi). Lake Dianchi $\left(24^{\circ} 51^{\prime} \mathrm{N}, 102^{\circ} 42^{\prime} \mathrm{E}\right)$ lies in the center of the watershed, with an area of $309.5 \mathrm{~km}^{2}$ and a storage capacity of 1.56 billion $\mathrm{m}^{3}$ (at a water level of $1887.4 \mathrm{~m}$ ). As the largest lake on the Yunnan-Guizhou Plateau and the sixth-largest freshwater lake in China, Lake Dianchi has been given the name of "Pearl of the Plateau" concerning its significant functions for water supply, flood regulation, fisheries and biodiversity conservation (Wang et al., 2009; Zhao et al., 2012). Although the Lake Dianchi basin area makes up only $13.9 \%$ of Kunming, it contributed $75.5 \%$ of the city's gross domestic product, acting as the most active economic area in Yunnan Province (Pan and Gao, 2010). Since the 1970s, the population and economy in Kunming have expanded rapidly,

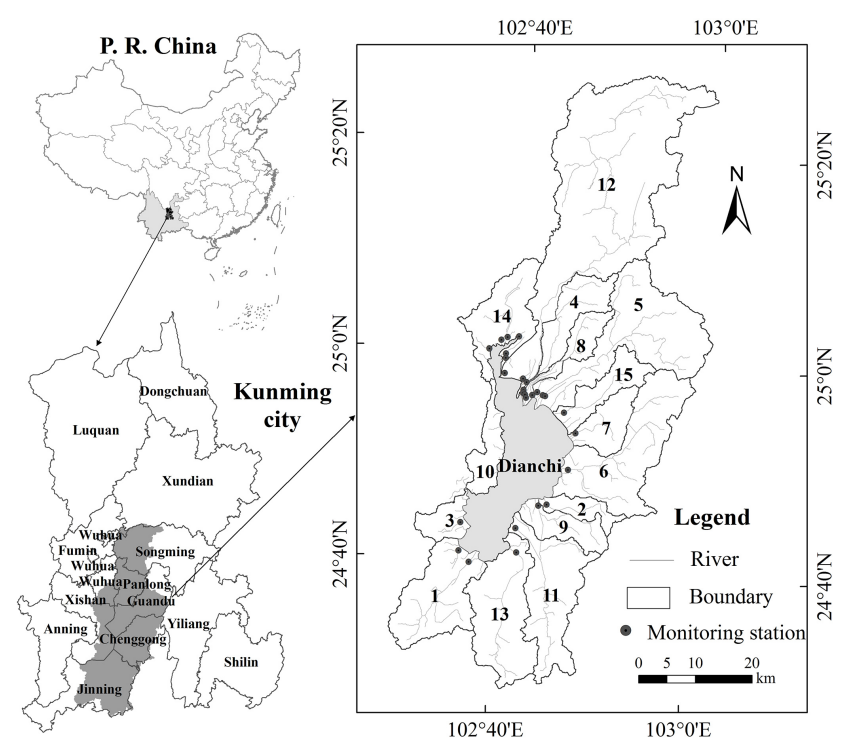

Figure 1. Location of the Lake Dianchi basin and the boundaries of its 15 catchments. The Lake Dianchi basin lies in the south of Kunming, the capital of Yunnan Province, China.

exerting great pressure on the water quality of Lake Dianchi (Liu et al., 2004; Pan and Gao, 2010). Over the last 40 years, the total population density in Kunming rose from 142 individuals per $\mathrm{km}^{2}$ in 1970 to 1260 individuals per $\mathrm{km}^{2}$ in 2010, while the gross domestic product increased 65-fold (data sources: Kunming Statistical Yearbook, 2011). As a result of great human disturbance, the water quality of Dianchi has deteriorated rapidly from Grade II (which is acceptable as a drinking water source or for rare species breeding) in the 1960s to worse than Grade V (which is unacceptable for any use) since 2000, according to the Chinese environmental quality standard for surface water (version GB 3838-2002). Although a lot of effort has been made to mitigate pollution, a steadily increasing trend is still obvious in nutrient concentrations, especially for $\mathrm{N}$ (Wang and Chen, 2009; Pan and $\mathrm{Gao}, 2010$ ). Enhanced $\mathrm{N}$ input from anthropogenic sources has been considered to be one of the most important factors leading to eutrophication in Lake Dianchi (Wang and Chen, 2009; He et al., 2010).

\subsection{Net anthropogenic nitrogen inputs (NANI) model}

Calculation of NANI is based on the conceptual model introduced by Howarth et al. (1996), in which NANI has four components: atmospheric deposition of oxidized $\mathrm{N}$ compound, fertilizer $\mathrm{N}$ application, agricultural $\mathrm{N}$ fixation, and net food and feed imports. NANI has been applied in many watersheds across the US (Howarth et al., 2006; Schaefer et al., 2009), Europe (Billen et al., 2011a; Hägg et al., 2012; Hong et al., 2012) and Asia (Hayakawa et al., 2009; Han et al., 2014), and some adjustments were made according to data availability or new concepts (Hong et al., 2013). In 
Table 1. Summary of catchment data on area, population and land use. Catchments 12 (Panlong), 5 (Baoxiang), and 6 (Laoyu) are the three biggest catchments in the Lake Dianchi basin, accounting for $45.2 \%$ of the total basin area. Collectively, catchments 4 (Daqing), 12 (Panlong), and 14 (Caohai) comprised $69.4 \%$ of the total population. There is great variety in natural and social characteristics.

\begin{tabular}{|c|c|c|c|c|c|c|c|c|c|}
\hline \multirow[t]{2}{*}{ Catchment } & \multirow[t]{2}{*}{ Name } & \multirow{2}{*}{$\begin{array}{l}\text { Area } \\
\left(\mathrm{km}^{2}\right)\end{array}$} & \multirow{2}{*}{$\begin{array}{l}\text { Pop. density } \\
\text { (ind. } \mathrm{km}^{-2} \text { ) }\end{array}$} & \multicolumn{6}{|c|}{ Land-use proportion (\%) } \\
\hline & & & & Cropland & Forest & Pasture & Waters & Urban & Unused \\
\hline 1 & Dongda & 188.2 & 733 & 24.1 & 58.3 & 5.3 & 1.3 & 8.3 & 2.7 \\
\hline 2 & Nanchong & 44.4 & 484 & 44.8 & 34.7 & 0.3 & 1.3 & 15.9 & 3.1 \\
\hline 3 & Gucheng & 49.9 & 433 & 23.5 & 48.4 & 4.2 & 2.6 & 14.3 & 7.1 \\
\hline 4 & Daqing & 99.9 & 5370 & 8.0 & 34.1 & 2.4 & 0.2 & 51.9 & 3.3 \\
\hline 5 & Baoxiang & 316.3 & 637 & 20.6 & 51.8 & 2.4 & 0.5 & 20.5 & 4.2 \\
\hline 6 & Laoyu & 263.5 & 375 & 29.9 & 48.2 & 1.4 & 1.0 & 15.5 & 4.0 \\
\hline 7 & Luolong & 79.0 & 1135 & 35.4 & 24.1 & 0.7 & 0.6 & 33.4 & 6.0 \\
\hline 8 & Haihe & 59.3 & 1876 & 15.3 & 36.4 & 1.7 & 0.8 & 41.2 & 4.6 \\
\hline 9 & Yuni & 74.7 & 697 & 47.7 & 35.2 & 0.4 & 1.0 & 14.4 & 1.3 \\
\hline 10 & Xian & 65.0 & 467 & 15.0 & 66.8 & 4.5 & 1.0 & 9.6 & 3.1 \\
\hline 11 & Baiyu & 205.0 & 393 & 23.9 & 60.2 & 2.0 & 0.5 & 11.1 & 2.3 \\
\hline 12 & Panlong & 740.7 & 1319 & 16.6 & 65.4 & 2.4 & 0.7 & 12.9 & 2.1 \\
\hline 13 & Cigang & 217.5 & 353 & 27.0 & 54.2 & 7.3 & 1.1 & 6.2 & 4.3 \\
\hline 14 & Caohai & 145.7 & 5259 & 7.6 & 35.5 & 1.7 & 0.4 & 51.4 & 3.4 \\
\hline 15 & Maliao & 84.8 & 883 & 35.2 & 30.9 & 2.2 & 0.7 & 22.9 & 8.1 \\
\hline Total basin* & & 2920.0 & 1125 & 19.9 & 47.3 & 2.5 & 10.8 & 16.5 & 3.0 \\
\hline
\end{tabular}

*Including Lake Dianchi.

this study, the calculation was based on the particular NANI approach presented by Howarth et al. (2006) with some adjustments as described below. In addition to other sources of food production, fruits and fishery products were added to the items of net food and feed import.

It has been reported that NANI calculations can be influenced by the methodology for extrapolating data from county to watershed areas (Han and Allan, 2008; Hong et al., 2013). An area-weighting method and a land use-weighting method were both used in this study to compare the results.

Data used in this study area include fertilizer use, human and livestock populations, atmospheric $\mathrm{NO}_{\mathrm{y}}$ deposition, crop products, meat production, land use, river flow, and water quality. Assisted by the Dianchi water pollution control program, land use with a resolution of $30 \mathrm{~m}$ in the year 2005 is interpreted and applied. Since the data and model results used in this paper have differing levels of uncertainty, we generally present NANI and its components to the nearest $100 \mathrm{~kg}-$ $\mathrm{N} \mathrm{km}^{-2} \mathrm{yr}^{-1}$.

\subsubsection{Atmospheric $\mathbf{N}$ deposition}

Atmospheric $\mathrm{N}$ deposition includes both reduced $\left(\mathrm{NH}_{\mathrm{y}}\right)$ and oxidized $\left(\mathrm{NO}_{\mathrm{y}}\right)$ forms, but only $\mathrm{NO}_{\mathrm{y}}$ is considered to be an $\mathrm{N}$ input for NANI here, assuming that most of the $\mathrm{NH}_{\mathrm{y}}$ deposition originates from $\mathrm{NH}_{\mathrm{X}}$ emission within the same watershed and that atmospheric transport of reduced $\mathrm{N}$ either into or out of a watershed is negligible relative to other inputs (Howarth et al., 2006). This assumption becomes increasingly questionable as the size of a watershed becomes smaller (Boyer et al., 2002; Howarth et al., 2012), but is not an issue so long as the net cross-catchment transfers in the atmosphere is small, with atmospheric fluxes entering the catchment equaling those leaving. Given the relatively homogenous land use in the area studied (the average proportion of farmland in the 15 catchments is 0.23 , with a standard variation of 0.08 ), we believe this assumption is reasonable for the basin. Howarth et al. (2012) reported that for a set of 150 watersheds in North America and Europe, the NANI approach of ignoring $\mathrm{NH}_{\mathrm{y}}$ deposition appeared to be robust down to catchments as small as $250 \mathrm{~km}^{2}$. Although some of the catchments here are even smaller, other NANI inputs are so large that we remain confident in not including $\mathrm{NH}_{\mathrm{y}}$ deposition. Total $\mathrm{NO}_{\mathrm{y}}$ deposition (both dry and wet) of the Lake Dianchi basin was estimated from global model outputs obtained from a previous study (Lamarque et al., 2010). The atmospheric $\mathrm{NO}_{\mathrm{y}}$ deposition was calculated on the global scale, covering several years in the 2000s at a horizontal resolution of $0.5^{\circ}$ in latitude and longitude. For the Lake Dianchi basin, only two grids (with $\mathrm{NO}_{\mathrm{y}}$ deposition values of 305 and $330 \mathrm{~kg} \mathrm{~N} \mathrm{~km}^{-2}$, respectively) were involved in the study area. By area-weighting methodology, $\mathrm{NO}_{\mathrm{y}}$ deposition in the 15 catchments varies from 312 to $331 \mathrm{~kg} \mathrm{~N} \mathrm{~km}^{-2}$. Since $\mathrm{NO}_{\mathrm{y}}$ deposition is not a significant source for NANI in this basin and the estimates of deposition in neighboring model grid cells involved are relatively homogeneous, we think this model is appropriate for this small study site. 


\subsubsection{Fertilizer $\mathrm{N}$ application}

Nitrogen inputs from fertilizer are based on the seven counties' fertilizer use from the Kunming Statistic Book from 2001 and 2011. Data are reported separately for $\mathrm{N}$ fertilizers and for compound fertilizers. We use the sum of $\mathrm{N}$ fertilizer and $\mathrm{N}$ in compound fertilizer assuming an average $\mathrm{N}$ proportion in compound fertilizer of $32.6 \%$ (Zhang et al., 2009). Since organic fertilizer (manure) is considered largely to be cycled within a watershed, it is not included in the NANI calculation (Howarth et al., 1996, 2012).

\subsubsection{Agricultural N fixation}

In the Lake Dianchi basin, the main legume crops include peanuts, soybeans, snap beans and alfalfa hay. Sown areas of these four crops were taken from the Kunming Statistic Book directly, while average values of $\mathrm{N}$ fixed per area was 8000 for peanuts, 9600 for soybeans, 9000 for snap beans and $22400 \mathrm{~kg} \mathrm{~N} \mathrm{~km}^{-2} \mathrm{yr}^{-1}$ for alfalfa hay (Smil, 1999; Boyer et al., 2002). Agricultural $\mathrm{N}$ fixation inputs were estimated by multiplying the crop area of these crops by the rate of fixation for each crop type.

\subsubsection{Net food and feed $\mathrm{N}$ import}

Net food and feed N import (NFFI) in the Lake Dianchi catchments was calculated as $\mathrm{N}$ consumed by humans and livestock, subtracted by $\mathrm{N}$ production in the catchment. Human $\mathrm{N}$ consumption was estimated by multiplying population by $\mathrm{N}$ consumption per capita. Rural and urban populations on the county scale were obtained from the Kunming Statistic Book, and N consumption per capita for rural and urban populations is estimated at 3.95 and $3.71 \mathrm{~kg} \mathrm{~N}$ capita ${ }^{-1} \mathrm{yr}^{-1}$, respectively, in Kunming (Zhai et al., 2005). A total of 8 types of animal populations on the county scale were collected from the Kunming Statistic Book, and their $\mathrm{N}$ requirement levels were derived from previous studies (Boyer et al., 2002; Van Horn, 1998). Food $\mathrm{N}$ production was estimated from 18 main crops and 3 fish species comprising the bulk of the local fishery (about $85 \%$ of the fish production is from aquaculture in the basin) on the county scale from the Kunming Statistic Book, and their $\mathrm{N}$ content value derived from the China food nutrient form (Wang, 2009).

\subsection{Calculation of riverine $\mathrm{N}$ export}

We estimated riverine $\mathrm{N}$ export from river discharge and $\mathrm{TN}$ concentrations on a multiple-year average basis. A total of 1519 samples of monthly flow data (plus daily flow from 14 rivers during 2009 and 2011) and 1930 monthly total nitrogen concentrations for 31 rivers covering the years 2001 to 2010 from the Kunming monitoring center were collected. N fluxes of these 31 rivers were then aggregated to 15 catchments according to their geographical position. Since the data collected are subject to skewed distribution, median values of discharge and TN concentration in multiple years were used in this study. TN export in catchment $i$ was estimated as

$\mathrm{NE}_{j}=\left(C_{j} \times F_{j}\right) \times 31536$

$\mathrm{TNE}_{i}=\sum_{j} \mathrm{NE}_{j} / A_{i}$,

in which NE refers to TN export in river $j\left(\mathrm{~kg} \mathrm{Nyr}^{-1}\right)$; $C$ and $F$ stand for medians of TN concentration $\left(\mathrm{mg} \mathrm{L}^{-1}\right)$ and river discharge rate $\left(\mathrm{m}^{3} \mathrm{~s}^{-1}\right)$ based on multiple-year monthly or daily data; TNE denotes TN export in catchment $i\left(\mathrm{~kg} \mathrm{~N} \mathrm{~km}^{-2} \mathrm{yr}^{-1}\right) ; A$ is the area of each catchment $\left(\mathrm{km}^{2}\right) ; i$ is the identification number for the 15 catchments in the Lake Dianchi basin, and $j$ is an index of each river in a catchment; 31536 is a conversion factor.

\section{Results}

\subsection{NANI estimates in the Lake Dianchi basin based on the area-weighting method}

NANI calculations in this study were made on the county scale, which is the smallest administrative unit at which data were collected. To estimate data from county to catchment, area weighting is the most commonly used method. In this method, NANI and its four components in each catchment are calculated by multiplying the value in each county by its area proportion in the catchment. A total of seven counties were involved in the calculation, with an average area of $776 \mathrm{~km}^{2}$ compared to an average of $175 \mathrm{~km}^{2}$ for the 15 catchments. On the whole Lake Dianchi basin basis, NANI reached $11600 \mathrm{~kg} \mathrm{~N} \mathrm{~km}^{-2} \mathrm{yr}^{-1}$. Fertilizer $\mathrm{N}$ input is the largest component, with a value of $6700 \mathrm{~kg} \mathrm{~N} \mathrm{~km}^{-2} \mathrm{yr}^{-1}$, followed by net food and feed import $\left(4400 \mathrm{~kg} \mathrm{~N} \mathrm{~km}^{-2} \mathrm{yr}^{-1}\right)$, atmospheric $\mathrm{NO}_{\mathrm{y}}$ deposition $\left(330 \mathrm{~kg} \mathrm{~N} \mathrm{~km}^{-2} \mathrm{yr}^{-1}\right)$, and agricultural $\mathrm{N}$ fixation $\left(220 \mathrm{~kg} \mathrm{~N} \mathrm{~km}^{-2} \mathrm{yr}^{-1}\right)$. Nitrogen inputs from fertilizer and food dominate in the Lake Dianchi basin, which reflects the combined pressure from agricultural development and population expansion. On the catchment scale (Fig. 2), NANI estimates from the 15 catchments range from 8300 to $14200 \mathrm{~kg} \mathrm{~N} \mathrm{~km}^{-2} \mathrm{yr}^{-1}$, largely again from fertilizer $\mathrm{N}$ input and NFFI. Catchments in the central city (catchments 14, 4, 8, 5, 12, and 15), are the largest $\mathrm{N}$ input areas. Compared to other watersheds over the world, NANI in the Lake Dianchi basin is high, i.e., in the northeastern US (560 to $4500 \mathrm{~kg} \mathrm{~N} \mathrm{~km}^{-2} \mathrm{yr}^{-1}$ ) (Howarth et al., 2006), the southeastern US ( 2700 to $4900 \mathrm{~kg} \mathrm{~N} \mathrm{~km}^{-2} \mathrm{yr}^{-1}$ ) (Schaefer and Alber, 2007), Baltic Sea catchments (300 to $8800 \mathrm{~kg} \mathrm{~N} \mathrm{~km}^{-2} \mathrm{yr}^{-1}$ ), and Europe generally (less than 1000 to over $20000 \mathrm{~kg} \mathrm{~N} \mathrm{~km}^{-2} \mathrm{yr}^{-1}$ ) (Billen et al., 2011b). Such a high value of an $\mathrm{N}$ input is likely responsible for the serious aquatic $\mathrm{N}$ pollution in this region. 


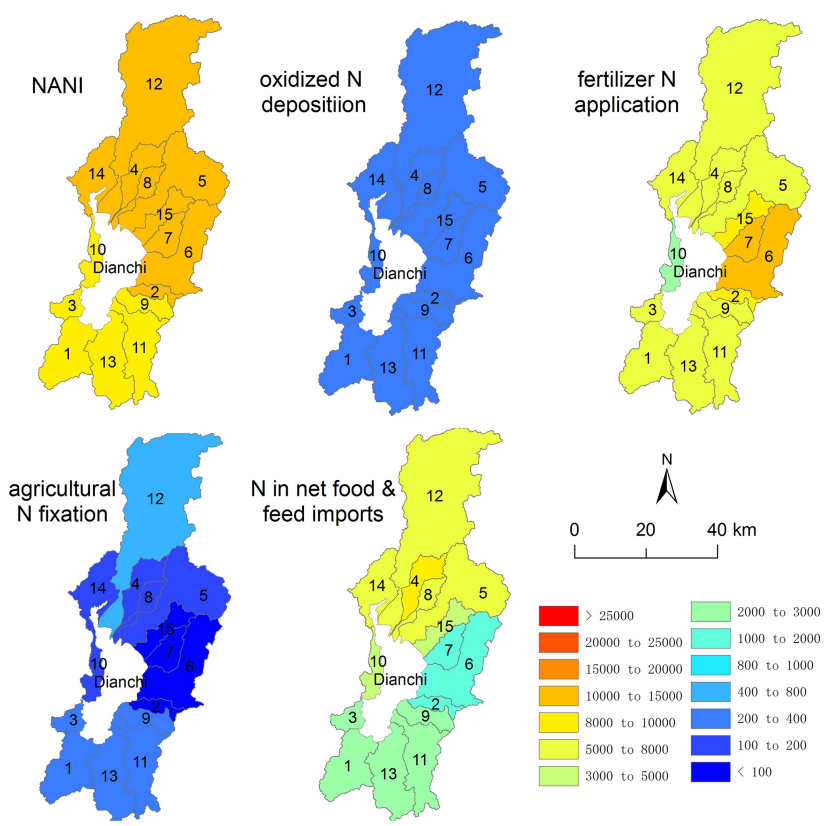

Figure 2. NANI $\left(\mathrm{kg} \mathrm{N} \mathrm{km}^{-2} \mathrm{yr}^{-1}\right)$ and its components for the Lake Dianchi basin based on the area-weighting method. Overall, NANI in north Dianchi is larger than the south, and fertilizer is the biggest nitrogen input for most catchments.

\subsection{NANI estimates in the Lake Dianchi basin based on the land use-weighting method}

The area-weighting method described in the previous section assumes that all components are distributed evenly over all land use categories. Obviously, the assumption is in error in some cases, and extrapolation based on land use-weighting has been suggested to deal with this problem (Han and Allan, 2008). However, when the calculation is carried out on a large scale or where land use does not vary significantly, there is little difference between area-weighting and land use-weighting methods (Han and Allan, 2008). To compare the suitability of these two methods in small watersheds, a NANI calculation for the Lake Dianchi basin based on landuse weighting was applied in this study. Apart from atmospheric $\mathrm{N}$ deposition, which was evenly distributed across all land use, fertilizer $\mathrm{N}$ input, agricultural $\mathrm{N}$ fixation, and crop $\mathrm{N}$ production were allocated to farmland, and all components of net food and feed $\mathrm{N}$ imports other than crop $\mathrm{N}$ production were designated on resident land. Because animal production sites in this basin are in close proximity to residential areas, we attributed these activities to residential land instead of to agricultural (crop) land, as some researchers have done elsewhere (Han and Allan, 2008; Hong et al., 2013).

A slightly smaller value of NANI of $9900 \mathrm{~kg} \mathrm{~N} \mathrm{~km}^{-2} \mathrm{yr}^{-1}$ was observed for the whole Lake Dianchi basin by the land use-weighting method. Nitrogen inputs from fertilizer and food import are still the dominant sources, which are 6500 and $2800 \mathrm{~kg} \mathrm{~N} \mathrm{~km}^{-2} \mathrm{yr}^{-1}$, respectively. Agricultural $\mathrm{N}$ fix-

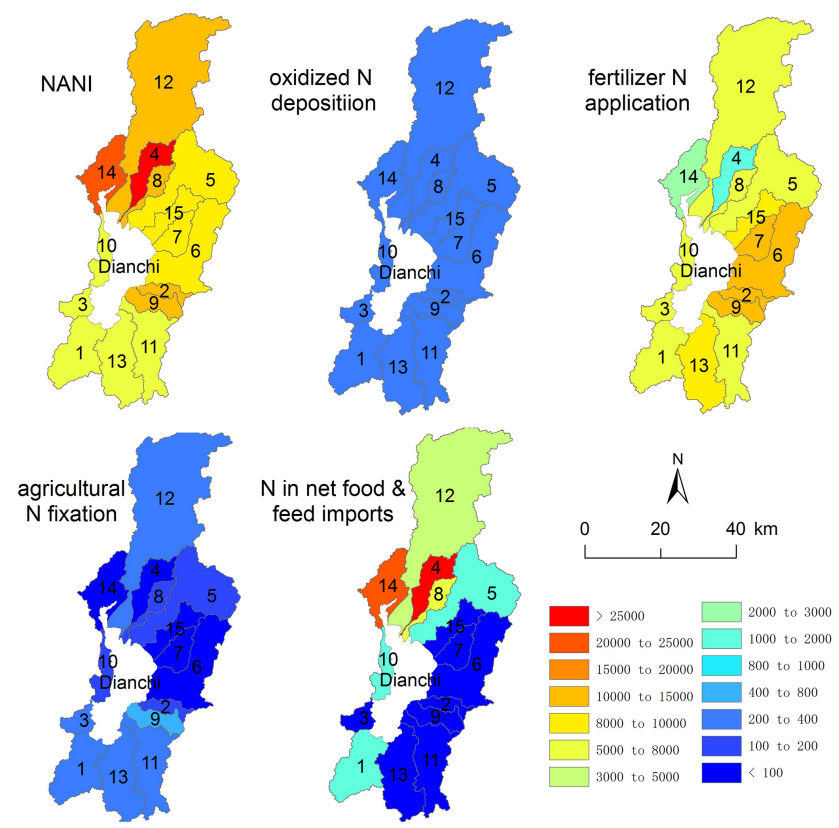

Figure 3. NANI $\left(\mathrm{kg} \mathrm{N} \mathrm{km}^{-2} \mathrm{yr}^{-1}\right)$ and its components for the Lake Dianchi basin based on the land use-weighting method. A high value of NANI and its components could be observed in this method, especially for catchments 4,14 , and 8 .

ation has a similar value of $220 \mathrm{~kg} \mathrm{~N} \mathrm{~km}^{-2} \mathrm{yr}^{-1}$, while deposition remains the same as in the area-weighting method (330 kg N km${ }^{-2} \mathrm{yr}^{-1}$ ). On the catchment scale (Fig. 3), however, the two approaches for estimating NANI show greater differences, as we discuss further in the following section.

\section{Discussion}

\subsection{Influence of data extrapolation methods on NANI}

A significant difference was observed in terms of NANI for the catchments between the two methods of data extrapolation (Table 2). For the results from the area-weighting method, NANI estimates for catchments ranged from 8300 to $14200 \mathrm{~kg} \mathrm{~N} \mathrm{~km}^{-2} \mathrm{yr}^{-1}$. For the land use-weighting method, NANI ranged from 6600 to $28000 \mathrm{~kg} \mathrm{~N} \mathrm{~km}^{-2} \mathrm{yr}^{-1}$. The relative difference between the two methods in the 15 catchments varies between 5 and $100 \%$. Catchment 4 , which lies in the center of Kunming, varied the most in NANI between the two approaches. Since this catchment has a high population density, larger values of food $\mathrm{N}$ import (over $200 \%$ ) were observed compared to the area-weighting method. Thus, we could conclude that land use is not evenly distributed among catchments, and this cannot be ignored. However, over the whole Lake Dianchi basin basis, the relative difference between the two extrapolation methods is only $15 \%$, suggesting that the area-weighting method of NANI calculation is 
Table 2. Comparison of NANI and relative error in the 15 catchments (unit: $\mathrm{kg} \mathrm{N} \mathrm{km}^{-2} \mathrm{yr}^{-1}$ ). Catchments with a higher proportion of farmland and resident land have a relatively larger change.

\begin{tabular}{lrrr}
\hline $\begin{array}{l}\text { Catchment } \\
\text { ID }\end{array}$ & $\begin{array}{r}\text { Area } \\
\text { weighting }\end{array}$ & $\begin{array}{r}\text { Land-use } \\
\text { weighting }\end{array}$ & $\begin{array}{r}\text { Difference } \\
(\%)\end{array}$ \\
\hline 1 & 8800 & 7000 & -21 \\
2 & 11800 & 11300 & -5 \\
3 & 8800 & 7400 & -15 \\
4 & 14200 & 28000 & 100 \\
5 & 13900 & 9600 & -31 \\
6 & 12300 & 8500 & -31 \\
7 & 12300 & 8400 & -32 \\
8 & 14000 & 13400 & -5 \\
9 & 9600 & 13200 & 38 \\
10 & 8300 & 6600 & -21 \\
11 & 8800 & 7300 & -17 \\
12 & 13100 & 11100 & -15 \\
13 & 8800 & 8000 & -9 \\
14 & 13500 & 24000 & 79 \\
15 & 13000 & 9300 & -29 \\
Total basin & 11600 & 9900 & -15 \\
\hline
\end{tabular}

valid on a large scale (in this study, $2920 \mathrm{~km}^{2}$ ), which is consistent with the findings of others (Han and Allan, 2008).

\subsection{Response of riverine $\mathrm{N}$ export to NANI}

Nitrogen export via river flux is an important output for $\mathrm{N}$ budgets, and is also a driver for aquatic ecosystem degradation. We estimate $\mathrm{N}$ inputs to Lake Dianchi from the 15 catchments to be approximately $8.0 \mathrm{Gg} \mathrm{Nyr}^{-1}$, in good agreement with the $\mathrm{TN}$ emission of $9.8 \mathrm{Gg} \mathrm{N}$ in 2005 (cited from water pollution control planning of the Lake Dianchi basin for 2006 to 2010). Of the 15 catchments, rivers in catchments 14, 12, and 4 carried the most TN load, making up $37 \%, 24 \%$, and $15 \%$ of the total riverine export. When expressed per area of watershed, catchment 14 $\left(20000 \mathrm{~kg} \mathrm{~km}^{-2} \mathrm{yr}^{-1}\right)$ and $4\left(12000 \mathrm{~kg} \mathrm{~km}^{-2} \mathrm{yr}^{-1}\right)$ are the largest sources of $\mathrm{N}$. Interestingly, the biggest (catchment 12) was not among the top values because of its large area, but catchment 8 became the third-highest $\mathrm{N}$ flux per area $\left(12000 \mathrm{~kg} \mathrm{~km}^{-2} \mathrm{yr}^{-1}\right)$. For other catchments, there is a good coincidence in ranking between fluxes from absolute values and area-specific values (Fig. 4).

The relationship between $\mathrm{N}$ input and riverine TN export is often fitted by linear or exponential functions, with statistically significant goodness of fit (Howarth et al., 1996; Han et al., 2009). Howarth et al. $(1996,2012)$ estimated an average of $20 \%$ to $25 \%$ NANI was exported in rivers for major watersheds in North America and Europe. However, the proportion of NANI being exported through rivers varies a lot in different catchments, ranging from less than $10 \%$ to $50 \%$ or more (Howarth et al., 1996; 2006; 2012; Schaefer and Alber, 2007; Hong et al., 2012). In this study,

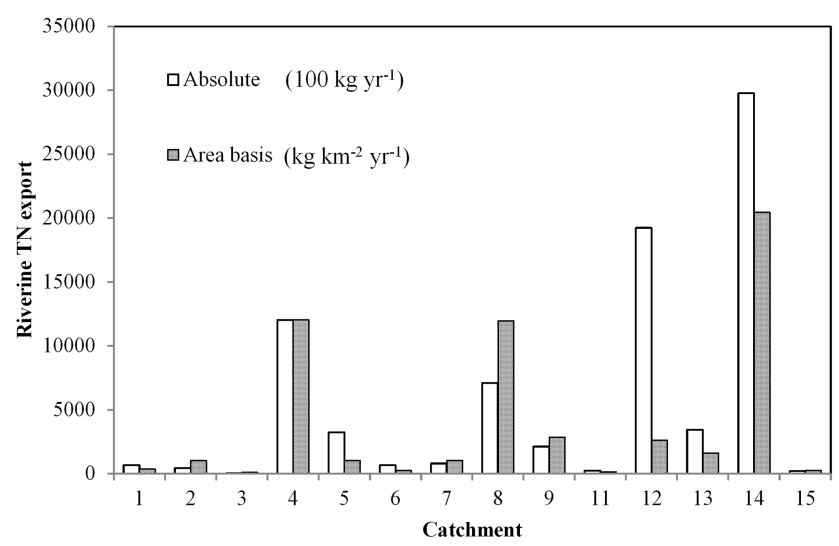

Figure 4. Riverine N export from 15 catchments in the Lake Dianchi basin. Catchments 4,12 , and 14 comprised $76.2 \%$ of the total riverine $\mathrm{N}$ input, and catchment 14 is the highest both on the basis of absolute flux or flux per area, while catchment 12 ranks differently when expressed per area of watershed. Catchment 10 is omitted here because there are no monitoring stations there.

the proportion of NANI exported by rivers suggested by the slope of the linear regression line reached $150 \%$ using the area-weighting method and $83 \%$ using the land use-weighting method (Fig. 5). Riverine $\mathrm{N}$ export exceeding $100 \%$ of anthropogenic $\mathrm{N}$ inputs to catchments is not sustainable and is physically unrealistic. The $150 \%$ proportion suggested by the regression of the area-weighting calculation is not statistically significant $(p>0.05)$, has low explanatory power $\left(R^{2}=0.27\right)$, and is unrepresentative of the real response of riverine $\mathrm{N}$ export to NANI. However, more reasonable results were observed using the land useweighting method, which indicated that a $83 \%$ to $(95 \%$ confidence interval of $51 \%$ to $114 \%$ ) of NANI was exported in rivers (Fig. 5b). Although this value is still much larger than the results from past research, the slope of the linear relationship is highly significant $(p<0.0001)$. In addition, study in watersheds in the US and some western countries also showed that larger proportions of NANI would be exported in rivers when NANI exceeds some threshold value (e.g., $1070 \mathrm{~kg} \mathrm{~N} \mathrm{~km}^{-2} \mathrm{yr}^{-1}$, Howarth et al., 2012), which can be explained partly by loads overwhelming the limited capacity for retention and denitrification in watersheds. In the Lake Dianchi basin, NANI in most catchments is ten times higher than the $1070 \mathrm{~kg} \mathrm{~N} \mathrm{~km}^{-2} \mathrm{yr}^{-1}$ threshold, providing some credibility to the notion that loads exceed retention capacity. In addition, smaller watersheds have shorter flowpaths and retention times resulting in less retention or denitrification. Finally, the well-developed drainage-pipe network in urban areas (further details can be found in next section) where $\mathrm{N}$ inputs are concentrated may also be responsible for accelerating $\mathrm{N}$ transport while decreasing loss from denitrification and leakage, analogous to the role played by tile drainage in agricultural watersheds of the Midwestern US and elsewhere (McIsaac and $\mathrm{Hu}, 2004)$. The y intercept 


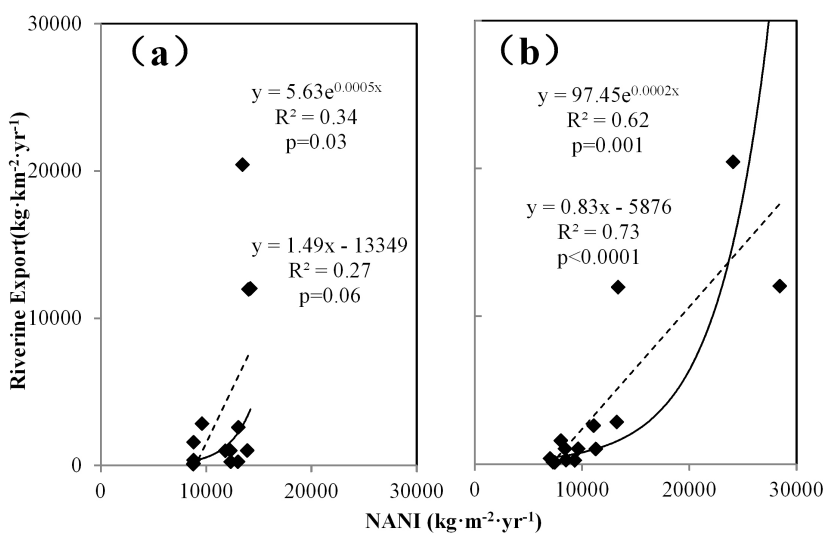

Figure 5. Comparison of relationships between NANI and riverine $\mathrm{N}$ export. Results from the area-weighting method (a) and the land use-weighting method (b). Dashed line represents linear fitting results and solid line is for an exponential fitting. Relationships from both fitting functions were significant $(p<0.01)$ for the land useweighting method, but neither linear nor exponential relationships were found to be statistically significant in results from the areaweighting method.

of the linear fit function is significantly negative, with a value about -5900 (95\% confidence interval of -1600 to $-10100) \mathrm{kg} \mathrm{km}^{-2}$ (Fig. 5). If the linear function is taken literally, the negative intercept $(p=0.01)$ implies that there may be no or little $\mathrm{N}$ exported in riverine flux when $\mathrm{N}$ inputs from anthropogenic activities are lower than a threshold value of NANI of around $7100 \mathrm{~kg} \mathrm{~km}^{-2} \mathrm{yr}^{-1}$. However, since there are few data below around $7100 \mathrm{~kg} \mathrm{~km}^{-2} \mathrm{yr}^{-1}$ in NANI, more detailed monitoring data are needed to verify this response. Alternatively, the response of riverine $\mathrm{N}$ flux could be assumed to be nonlinear (Han et al., 2009). When an exponential function was used to fit the relationship between NANI and N riverine export, we also observed a significant response in the land use-weighting results (Fig. 5), so we cannot rule out the possibility of a smooth but nonlinear relationship between NANI and N riverine export in the catchments of the Lake Dianchi basin, in which the proportion of NANI exported in rivers increases steadily with increasing NANI, without a specific threshold response.

\subsection{Influence of small spatial scales on NANI calculations}

Compared to the watersheds in other studies using NANI methods, the Lake Dianchi basin is relatively small in size, imposing challenges for obtaining reliable data to characterize the components of NANI. The suitability of the methodology of extrapolating data from county-level data should be carefully examined. As put forth above, the specific method used for data extrapolation did have a crucial influence on the NANI calculations in the Lake Dianchi basin. To assess the applicability of land use-weighting methodology that is also (a)

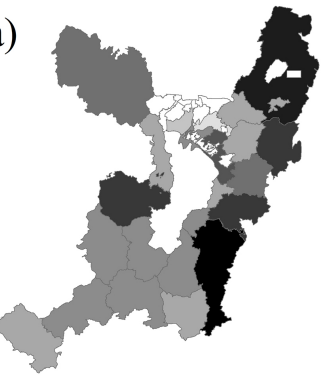

(c)

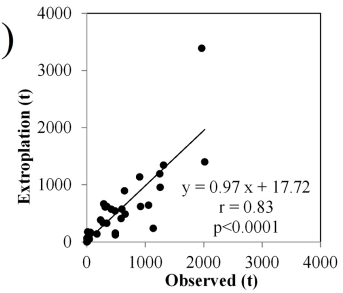

(b)

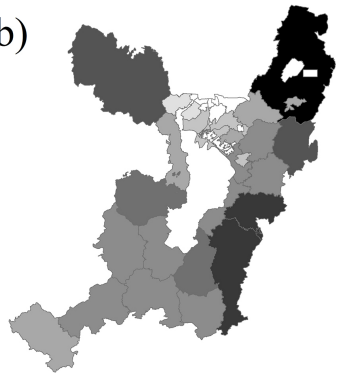

Nitrogen Fertilizer Application (t)

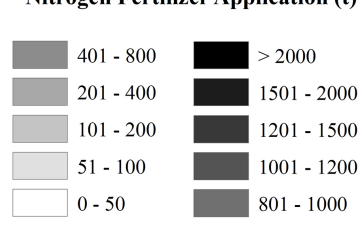

Figure 6. Comparison of $\mathrm{N}$ fertilizer use between (a) observed and (b) extrapolated values in the 35 towns of Xishan, Guandu, Jinning and Chenggong counties in 2007. The size of the towns is small, varying from $3 \mathrm{~km}^{2}$ to $424 \mathrm{~km}^{2}$, with an average of $86 \mathrm{~km}^{2}$, less than half of the average area of catchments in the basin. Data extrapolated from the county using the land use-weighting method is in good agreement with actual values.

recommended here, we applied it in estimating the town's data from county-level data. We selected four counties (Xishan, Guandu, Jinning and Chenggong; Fig. 6) involved in the basin, in which fertilizer application data of towns in 2007 are collected from references in local agricultural statistics. There are a total of 35 towns in the four counties, which range in size from $3 \mathrm{~km}^{2}$ to $424 \mathrm{~km}^{2}$, with an average of $86 \mathrm{~km}^{2}$, smaller than the catchments in the basin $\left(175 \mathrm{~km}^{2}\right)$. Firstly, $\mathrm{N}$ fertilizer use on a county basis was designated on agricultural land, and then summarized by a town boundary using GIS tools to obtain extrapolated $\mathrm{N}$ fertilizer use in towns. The comparison between actual values and estimated values in the towns is presented in Fig. 6. The extrapolated $\mathrm{N}$ fertilizer use pattern is consistent with observations on the town scale, and successfully distinguished the high- and low-value areas. The relationship between observed and extrapolated values is strong and statistically significant $(r=0.83, p<0.0001)$. In addition, the slope of the relationship is close to $1(0.97)$, with a relatively small y intercept $(17.71 \mathrm{t})$. Overall, the reproduction of $\mathrm{N}$ fertilizer data in towns from the county scale suggests that data extrapolation from county level in NANI calculation is valid when detailed land use is made.

When the size of a watershed becomes smaller, sewage transfer between watersheds may become an increasingly important question. In the Lake Dianchi basin, six major sewage treatment plants have been constructed in the last decade, most of which are located in central urban areas (Fig. 7). From the years 2007 to 2009, annual TN fluxes discharged from these plants had reached $2.5 \mathrm{Gg}$, occupying 

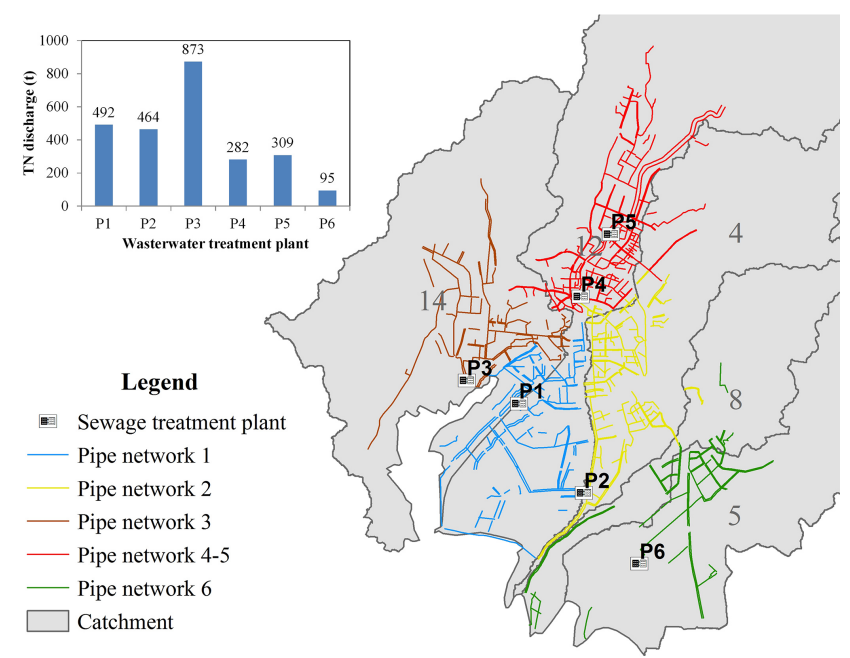

Figure 7. Main sewage treatment plants in the basin and their cover scope. In the study period, there are a total of six major plants to treat sewage in the basin, and all of them are located in the urban area. In spite of small overlaps between wastewater pipe networks discharged to different plants, sewage transportations are mostly confined in one catchment.

$31 \%$ of total riverine TN export. However, the scope of sewage pipe network in each sewage treatment plant (Fig. 7) is confined in just one catchment, and pipe networks from different plant are not heavily overlapped. Therefore, sewage transfer should not be a key problem in estimating NANI inputs in this study.

NANI estimates in the 15 catchments of the Lake Dianchi basin were quantified by both an area-weighting method and a land use-weighting method based on data from the years 2000 to 2010. Enhanced NANI was observed in the Lake Dianchi basin, and its high value of NANI ranks it at the top of watersheds in the world in terms of $\mathrm{N}$ loading. Agricultural production has greatly influenced NANI of the basin, and $\mathrm{N}$ input from fertilizer was the largest input source overall, dominating 12 out of the 15 catchments. Nitrogen from fertilizer and food dominates NANI, which implies a mixed stress from agricultural and population development. Based on county data, relatively small differences (relative differences of $15 \%$ ) in NANI calculations were observed between the area- and land use-weighting methods for the whole Lake Dianchi basin $\left(2920 \mathrm{~km}^{2}\right)$. However, on subwatershed scales (areas range from tens to hundreds of $\mathrm{km}^{2}$ ), NANI results based on the land use-weighting method were found to be more reliable (better $R^{2}$, better significance level, better consistency with past research) than results from the areaweighting method. When NANI is evaluated in small catchments where strong human disturbances exist, there might be evidence of a threshold for NANI to enable riverine nitrogen export. In the Lake Dianchi basin, when NANI is lower than around $7100 \mathrm{~kg} \mathrm{~km}^{-2} \mathrm{yr}^{-1}$, little or no riverine $\mathrm{N}$ export was observed. Alternatively, a nonlinear (exponential) func- tion may plausibly describe the response of riverine $\mathrm{N}$ export to NANI in this basin. Through data validation, the NANI model is believed to be valid in small watersheds $\left(\sim 100 \mathrm{~km}^{2}\right)$ when sufficiently high-resolution land use and other data are available to support estimates of the components of NANI. With additional monitoring and research on human activities in the region, more data may reveal the more accurate relationship between $\mathrm{N}$ inputs and riverine $\mathrm{N}$ fluxes from the Lake Dianchi basin.

Acknowledgements. This work was supported by grant from the China Scholarship Council and China Water Pollution Control and Technology Program (2013ZX07102). The authors are grateful to two anonymous reviewers for their constructive suggestion.

Edited by: N. Ohte

\section{References}

Billen, G., Grizzetti, B., Leip, A., Garnier, J., Voss, M., Howarth, R. Bouraoui, F., Lepistö, A., Kortelainen, P., and Johnes, P.: Nitrogen flows from European regional watersheds, in: The European Nitrogen Assessment: Sources, Effects and Policy Perspectives, edited by: Billen, G., Cambridge University Press, London, 271297, 2011a.

Billen, G., Silvestre, M., Grizzetti, B., Leip, A., Garnier, J., Voss, M., Howarth, R., Bouraoui, F., Lepistö, A., Kortelainen, P., Johnes, P., Curtis, C., Humborg, C., Smedberg, E., Ksate, Ø., Ganeshram, R., Beusen, A., and Lancelot, C.: Nitrogen flows from European regional watersheds to coastal marine waters, in: The European Nitrogen Assessment: Sources, Effects and Policy Perspectives, edited by: Billen, G., Cambridge University Press, London, 271-297, 2011b.

Boyer, E. W., Goodale, C. L., Jaworsk, N. A., and Howarth, R. W.: Anthropogenic nitrogen sources and relationships to riverine nitrogen export in the northeastern USA, Biogeochemistry, 57, 137-169, 2002.

Carpenter, S. R., Caraco, N. F., Correll, D. L., Howarth, R. W., Sharpley, A. N., and Smith, V. H.: Nonpoint pollution of surface waters with phosphorus and nitrogen, Ecol. Appl., 8, 559-568, 1998.

Crutzen, P. J.: Geology of mankind, Nature, 415, 23-23, 2002.

Galloway, J. N.: The global nitrogen cycle: changes and consequences, Environ. Pollut., 102, 15-24, 1998.

Galloway, J. N., Aber, J. D., Erisman, J. W., Seitzinger, S. P., Howarth, R. W., Cowling, E. B., and Cosby, B. J.: The nitrogen cascade, Bioscience, 53, 341-356, 2003.

Galloway, J. N., Dentener, F. J., Capone, D. G., Boyer, E. W., Howarth, R. W., Seitzinger, S. P., Asner, G. P., Cleveland, C. C., Green, P. A., Holland, E. A., Karl, D. M., Michaels, A. F., Porter, J. H., Townsend, A. R., and Vorosmarty, C. J.: Nitrogen cycles: past, present, and future, Biogeochemistry, 70, 153-226, 2004.

Gao, W., Zhou, F., Guo, H. C., Zhen, Y. X., Yang, C. L., Zhu, X., Li, N., Liu, W. H., Sheng, H., Chen, Q., Yi, X., and Xiang, N.: High-resolution nitrogen and phosphorus emission inventories 
of Lake Dianchi Watershed, Acta Scientiae Circumstantiae, 33, 240-250, 2013.

Hägg, H. E., Humborg, C., Swaney, D. P., and Morth, C. M.: Riverine nitrogen export in Swedish catchments dominated by atmospheric inputs, Biogeochemistry, 111, 203-217, 2012.

Han, H. J. and Allan, J. D.: Estimation of nitrogen inputs to catchments: comparison of methods and consequences for riverine export prediction, Biogeochemistry, 91, 177-199, 2008.

Han, Y. G., Fan, Y. T., Yang, P. L., Wang, X. X., Wang, X. J., Tian, J. X., Xu, L., and Wang, C. Z. : Net anthropogenic nitrogen inputs (NANI) index application in Mainland China, Geoderma, 213, 87-94, 2014.

Han, Y. G., Li, X. Y., and Nan, Z.: Net anthropogenic nitrogen accumulation in the Beijing metropolitan region, Environ. Sci. Pollut. R., 18, 485-496, 2011.

Hayakawa, A., Woli, K. P., Shimizu, M., Nomaru, K., Kuramochi, K., and Hatano, R.: Nitrogen budget and relationships with riverine nitrogen exports of a dairy cattle farming catchment in eastern Hokkaido, Japan, Soil Sci. Plant Nutr., 55, 800-819, 2009

He, J., Xu, X. M., Chen, Y. B., and Zhang, K. L.: Change trend and reason analysis of point source pollution load of the Dianchi Lake Basin, China Engin. Sci., 12, 75-79, 2010.

Hong, B., Swaney, D. P., Morth, C. M., Smedberg, E., Hagg, H. E., Humborg, C., Howarth, R. W., and Bouraoui, F.: Evaluating regional variation of net anthropogenic nitrogen and phosphorus inputs (NANI/NAPI), major drivers, nutrient retention pattern and management implications in the multinational areas of Baltic Sea basin, Ecol. Model., 227, 117-135, 2012.

Hong, B. G., Swaney, D. P., and Howarth, R. W.: Estimating net anthropogenic nitrogen inputs to US watersheds: comparison of methodologies, Environ. Sci. Technol., 47, 5199-5207, 2013.

Howarth, R., Anderson, D., Cloern, J., Elfring, C., Hopkinson, C., Lapointe, B., Malone, T., Marcus, N., McGlathery, K., and Sharpley, A.: Nutrient pollution of coastal rivers, bays, and seas, Issues in Ecol., 7, 1-15, 2000.

Howarth, R., Chan, F., Conley, D. J., Garnier, J., Doney, S. C., Marino, R., and Billen, G.: Coupled biogeochemical cycles: eutrophication and hypoxia in temperate estuaries and coastal marine ecosystems, Front. Ecol. Environ., 9, 18-26, 2011.

Howarth, R., Swaney, D., Billen, G., Garnier, J., Hong, B. G., Humborg, C., Johnes, P., Morth, C. M., and Marino, R.: Nitrogen fluxes from the landscape are controlled by net anthropogenic nitrogen inputs and by climate, Front. Ecol. Environ., 10, 37-43, 2012.

Howarth, R. W.: An assessment of human influences on fluxes of nitrogen from the terrestrial landscape to the estuaries and continental shelves of the North Atlantic Ocean, Nutr. Cycl. Agroecosys., 52, 213-223, 1998.

Howarth, R. W.: Coastal nitrogen pollution: a review of sources and trends globally and regionally, Harmful Algae, 8, 14-20, 2008.

Howarth, R. W., Billen, G., Swaney, D., Townsend, A., Jaworski, N., Lajtha, K., Downing, J. A., Elmgren, R., Caraco, N., Jordan, T., Berendse, F., Freney, J., Kudeyarov, V., Murdoch, P., and Zhu, Z. L.: Regional nitrogen budgets and riverine N\&P fluxes for the drainages to the North Atlantic Ocean: natural and human influences, Biogeochemistry, 35, 75-139, 1996.

Howarth, R. W., Swaney, D. P., Boyer, E. W., Marino, R., Jaworski, N., and Goodale, C.: The influence of climate on average nitrogen export from large watersheds in the northeastern United States, Biogeochemistry, 79, 163-186, 2006.

Lamarque, J.-F., Bond, T. C., Eyring, V., Granier, C., Heil, A., Klimont, Z., Lee, D., Liousse, C., Mieville, A., Owen, B., Schultz, M. G., Shindell, D., Smith, S. J., Stehfest, E., Van Aardenne, J., Cooper, O. R., Kainuma, M., Mahowald, N., McConnell, J. R., Naik, V., Riahi, K., and van Vuuren, D. P.: Historical (1850-2000) gridded anthropogenic and biomass burning emissions of reactive gases and aerosols: methodology and application, Atmos. Chem. Phys., 10, 7017-7039, doi:10.5194/acp10-7017-2010, 2010.

Li, H., Wang, Y., Shi, L. Q., Mi, J., Song, D., and Pan, X. J.: Distribution and fractions of phosphorus and nitrogen in surface sediments from Dianchi Lake, China, Int. J. Environ. Res., 6, 195208, 2012.

Liu, Y., Chen, J. N., and Mol, A. P. J.: Evaluation of phosphorus flows in the Dianchi watershed, Southwest of China, Popul. Environ., 25, 637-656, 2004.

Liu, Z. H., Liu, X. H., He, B., Nie, J. F., Peng, J. Y., and Zhao, L.: Spatio-temporal change of water chemical elements in Lake Dianchi, China, Water Environ. J., 23, 235-244, 2009.

McIsaac, G. F. and Hu, X. T.: Net $\mathrm{N}$ input and riverine $\mathrm{N}$ export from Illinois agricultural watersheds with and without extensive tile drainage, Biogeochemistry, 70, 251-271, 2004.

Pan, M. and Gao, L.: The influence of socio-economic development on water quality in the Dianchi Lake, Engin. Sci., 12, 117-122, 2010.

Rockstrom, J., Steffen, W., Noone, K., Persson, A., Chapin, F. S., Lambin, E. F., Lenton, T. M., Scheffer, M., Folke, C., Schellnhuber, H. J., Nykvist, B., de Wit, C. A., Hughes, T., van der Leeuw, S., Rodhe, H., Sorlin, S., Snyder, P. K., Costanza, R., Svedin, U., Falkenmark, M., Karlberg, L., Corell, R. W., Fabry, V. J., Hansen, J., Walker, B., Liverman, D., Richardson, K., Crutzen, P., and Foley, J. A.: A safe operating space for humanity, Nature, 461, 472-475, 2009.

Schaefer, S. C. and Alber, M.: Temperature controls a latitudinal gradient in the proportion of watershed nitrogen exported to coastal ecosystems, Biogeochemistry, 85, 333-346, 2007.

Schaefer, S. C., Hollibaugh, J. T., and Alber, M.: Watershed nitrogen input and riverine export on the west coast of the US, Biogeochemistry, 93, 219-233, 2009.

Smil, V.: Nitrogen in crop production: an account of global flows, Global Biogeochem. Cy., 13, 647-662, 1999.

Steffen, W., Crutzen, P. J., and McNeill, J. R.: The Anthropocene: are humans now overwhelming the great forces of nature, Ambio, 36, 614-621, 2007.

Swaney, D. P., Hong, B. G., Ti, C. P., Howarth, R. W., and Humborg, C.: Net anthropogenic nitrogen inputs to watersheds and riverine $\mathrm{N}$ export to coastal waters: a brief overview, Current Opinion Environ. Sustain., 4, 203-211, 2012.

Townsend, A. R., Howarth, R. W., Bazzaz, F. A., Booth, M. S., Cleveland, C. C., Collinge, S. K., Dobson, A. P., Epstein, P. R., Keeney, D. R., Mallin, M. A., Rogers, C. A., Wayne, P., and Wolfe, A. H.: Human health effects of a changing global nitrogen cycle, Front. Ecol. Environ., 1, 240-246, 2003.

Van Horn, H. H.: Factors Affecting Manure Quantity, Quality, and Use, Dallas-Ft. Worth, 1998.

Vitousek, P. M., Aber, J. D., Howarth, R. W., Likens, G. E., Matson, P. A., Schindler, D. W., Schlesinger, W. H., and Tilman, D.: 
Human alteration of the global nitrogen cycle: sources and consequences, Ecol. Appl., 7, 737-750, 1997.

Vitousek, P. M. and Howarth, R. W.: Nitrogen limitation on land and in the sea - how can it occur, Biogeochemistry, 13, 87-115, 1991.

Wang, F. S., Liu, C. Q., Wu, M. H., Yu, Y. X., Wu, F. W., Lu, S. L., Wei, Z. Q., and $\mathrm{Xu}, \mathrm{G} .:$ Stable isotopes in sedimentary organic matter from lake dianchi and their indication of eutrophication history, Water Air Soil Poll., 199, 159-170, 2009.

Wang, G. Y.: China Food Nutrients Facts, Peking University Medical Press, Beijing, 2009.

Wang, H. M. and Chen, Y.: Change trend of eutrophication of Dianchi Lake and Reason Analysis in recent 20 years, Environ. Sci. Survey, 28, 57-60, 2009.
Yang, X. E., Wu, X., Hao, H. L., and He, Z. L.: Mechanisms and assessment of water eutrophication, J. Zhejiang Univ.-Sc. B, 9, 197-209, 2008.

Zhai, F. Y., He, Y. N., Wang, Z. H., Yu, W. T., Hu, Y. S., and Yang, X. G.: The status and trends of dietary nutrients intake of Chinese population, Acta Nutrimenta Sinica, 27, 181-184, 2005.

Zhang, W. F., Li, L. K., Chen, X. P., and Zhang, F. S.: The present status and existing problems in China's compund fertilizer development, Phosphate Compound Fertilizer, 24, 14-16, 2009.

Zhao, Y. L., Zhang, K., Fu, Y. C., and Zhang, H.: Examining landuse/land-cover change in the Lake Dianchi Watershed of the Yunnan-Guizhou Plateau of southwest China with remote sensing and GIS techniques: 1974-2008, Int. J. Environ. Healt. R., 9, 3843-3865, 2012. 